years be taken; that a fixed sum of 10. s, or more according to circumstances, be paid for each case; and that the amount per annum be increased or diminished ancording to the number of cases.

4. That an extra sum be paid for vaccination and midwifery, according to the distance; for fractures and clislocations of all kinds; for serious injuries; and for all suruical operations

5. That orders (except for urgent cases) - be delivered by a certain hour,--say ten o'clock.

This, I think, is a matter of very great importance, and demands the attention of the Poor-law Board. If an arrangement on this head could be effected, it would be an immense saving of time and trouble; for, from the lax, lavish, and irregular way in which orders are given, it frequently happens that the medical officer is in the immediate locality whence they are sent, just at the moment they rench their destination, thereby entailing on him the necessity of perhaps again and again going over the same ground on the same day, which might have been avoided had the orders been delivered at an appointed time. As no hardship zor inconvenience is found to arise from hospital patients being obliget to deliver their orders for admission at a stated hour named by the governors, $I$ can see no reason why paupers should not be compelled to observe some regularity in this respect.

6. That ieeches, and some of the more expensive drugs, together with all surgical appliances, be provided by the boards of guardians.

I am, Sir, your obenient servant,

Clichester, Jan. 180 9. ALLEN DUKE, M.D.

\section{PROPOSED SOCIETY OF ASSISTANTS.}

\section{To tive Elitor of T⿰工一工E LANCET.}

SIR, - There appeared some weeks ago several letters in THE LAxCEr concerning a Society to be or yanized for the aid of assistants. I have given the subject consideration, and have communicated with a large body of medical practitioners on the matter; and have received rumerous replies, suggestions, and promises of support, so soon as the larger body of assistants can come to some definite agreement anongst themselves. My first attempt would be this: if assistants are really heart and soul in this matter, $I$ am ready to take the trouble of receiving eommunications from them, and to enceavour to commence the Society, making it at head quarters a place of application for assistants and principals, either by letter or personally and to provile an allowance for assiatants when they are out of a situation, under certain regulations, upon payment of a small subscription-say $2 s .6 d$. per annum.

I shall feel obliged if you will give this publicity in your journal, as being the best means of furthering this object. I am, Sir, your obecient servant,

$$
\begin{aligned}
& \text { Sheerness, Feb. } 1859 . \\
& \text { MLartis H. IRving, } \\
& \text { A. Medical Assistant. }
\end{aligned}
$$

\section{FACIIE MODE OF CEPPING.}

To the Editor of THE LAšcem.

SIR, - A correspondent in THE LANCET of $J$ an. 15th, makes an excellent surgestion for the manufacture of cheap cupping. glasses of common green glass, such as may be readily and not grudgingly used by anyone when leeches are not to be had.

Let me offer a suggestion for a safe and easy mode of exharsting them. free from all the trouble of pumps and the danger of spirits and ethers, and which will answer equally well with a wine or liqueur glass as the best ground cupping. glass.

Wipe the glass you select for use quite ray, rrop into the bottom of it one drop of melting wax mom the cardle in your hand; on this lay the smallest inasinalule dossil of gun-cotton, a morsel not larger than a grain of rice will be enough. The softness of the wax will suffice to keep this in sita if but one fibre is entangled. Then set fire to it with a bit of lighted paper, holding the month of the glass up, and its edge close to the part of the body on which you mean to apply it. At the instant of the puffy explosion, invert the glass on the part. The vacuum formed is perfect, and the action immediate. You have no ugly scalds from half extinguished ether, no flames from its droppings on the patient's dress, \&e. The cotton may be carried about quite safely in the heal of your lancet-case; and instead of the deep ugly gashes of a scariticating machine, a few light superficial cuts rapiliy made with the shoulder of a lancet over the part will give less pain, less fright, and more blood.

Warley Depût, Janůry, 1859. Yours obediently,

\section{PROFESSIONAL ETIQUETTE.}

To the Editor of THE LA.NCET.

SrR, - The following letter displays such a truly rich specimen of medical etiquette, that I must beg you will give it a place in your publication, for the benefit of our profession. The writer of it has been in our town only about five months, and I think his production promises well for his future career. I must say, by way of a preface, that I was originally engaged to attend Mrs. D-, and when sent for, I was not at home; in consequence of which my servant went for the writer of the following epistle. I, however, arrived at home before he had any possibility of leaving his own house, and sent another of my servants to him to say that I had gone to attend my patient, and that he need not go.

Morpeth, Jan. 1859. I am, Sir, yours faithfully, ROBEET SHUTE, M.R.C.S.

\section{[COPY.]}

Morpeth, Jan. 18th, 1859.

Dear SrR,-I received a call this morning to attend Mrs. $\mathrm{D}-$ at - ; and when preparing to start, a message as her master had gone. Now I infer from this, that you had been asked in the first instance, but not being at home, or otherwise engaged, the man came for me. The case, therefore, became virtually mine, and you had no right to go after you knew that I had been called. This is not gentlemanly conduct, and, although submitied to on this occasion, I beg you to understand that in future, if called upon under similar circumstances, I shall pay my visit and claim my fee.

R. Shute, Esq., Morpeth. Yours respectfully,

\section{R. Paton.}

\section{THE PROPOSED ARMY MEDICAL SCHOOL AT CHATHAM.}

To the Editor of THE LANCET.

Sir,--As I am sure that you and all well-wishers to the profession take an interest in the affairs of the Army Medical Department, 1 am induced to address you relative to the Army Medical School about to be formed at Chatham.

A committee, presided over by Mr. Sidney Herbert, has been for some time sitting to arrange its details; and one of the difficulties which it would appear they have experienced has been in agreeing on who are to be the professors; the Director-General, the only military member of the committee, very properly holding that the chairs should be filled by officers of the department; and the ciril members contending that they should be given to civilian friends of their own. As the Army Medical School cannot be intended to afford instruction on general subjects better than that supplied by the civil schools, it would seem that the effort to appoint civilians to fill the chairs is intended to express that there are no officers of the department capable of teaching the specialties which the service requires; but this the department, I know, is by no means disposed to admit, inasmuch as there are officers who have offered to be tested by concour's as to their capabilities for s':ch duties, and who have had ample experience of service and disease in all our colonies and dependencies; in fact, the subjects to be tanght in a military medical school are those only which experience of service at home and abroad with soldiers can furnish, and hence the appointment of civilians to such offices can be considered in no other light than as a joke.

As I am anxions only to draw your attention to the matter on this occasion, I will not enter at any greater length on the subject, but subscribe myself

Fêb. 1859 . Your very obedient servant, AN ARMY SURgeon.

\section{SOME OBSERVATIONS ON THE}

\section{SUBJECT OF COMBINING THE PRACTICE OF} MEDICINE AND OBSTETRICY AND DISEASES OF WOMEN.

To the Editor of THE LANCET.

SIR,- May I call your attention to a very common but somewhat arbitrary practice, - that of a separation of Medicine from Obstetricy, enforced either by custom or by the rules of many hospitals in town and country. I hope that some member of the new Obstetrical Society will be induced to take up the 
subject, and vindicate the right and propriety of physicians to practise midwifery, if they desire to combiue these two departments of the profession. In many of our larce provincial towns, and generally in London, the physicians of hospitals and dispensaries are debarred from the privilege of practising midwifery. This prohibition seems to imply that obstetric science is an inferior science, and unwortby the dignity of a physician; at the same time it deprives physicians of a great source of professional income. Surely, in the present day, it ought not to be necessary to assert the high importance of a branch of the profession which is of sich deep interest to the welfare, the happiness, and safety of a large portion of the human race, - of our dearest relatives, of our mothers, our wives, our sisters, and all womankind, -in their hour of need. A knowledge of obstetrics demands as much experience, science, and dexterity, as either medicine or surgery. The illustrious names of William Hunter, Smellie, \&c., in former times, and in the present day the names of Lee, Simpson, Clarke, Ferguson, Rigby, Locock, Granville, Ramisbothan, Tyler Smith, West, Clowne, Oldham, Babington, Davis, and many others of note, are proofs that obstetrics engage the attention of firstclass physicians. These gentlemen are not less sound physicians because they practise mid wifery. How numerons, how serious, are the diseases incident to gestation and parturition! aud how extremely important to society that physicians should be equally cognizant of all the diseases of wonen, under whatever circumstances they may arise or exist! Neither the College of Physicians nor any other college, that I know of, has limited its members to an exclusive class of diseases, nor prevented their acting as accoucheurs. Why, then, do the laws of our hospitals and dispensaries, or the tyranny of custom, interfere with the liberty of a practitioner in choosing to unite these two branches of his profession, if he is desirous of combining them? The restriction is antiquated and absurd; it is humiliating to the status and dignity of gentlemen of the highest standing. The new Obstetrical Society contains a number of eminent men, and I hope some of them will come forward to protest against every obstacle to their freedom of action, and to urge upon the governors and subscribers to medical institutions to abolish the laws which narrow the usefulness of those institutions, and to throw open to all legally-qualitied practitioners the right to practise iu both branches of medicine and obstetrics. This is not the age to be fettered by the laxs of the past: progress and liberty are the order of the day. It is but justice to physicians holding public appointments, which generally bring no emolument, that they should derive pecuniary adrantage in a department which usually yields the largest fees, and which fumishes the most numerous and complicated forms of disease. Of course, if professional men choose to limit their practice to particular diseases or departments, they can always do so. In many cases, no doubt, there may be an advantage in subdivision of labour and intellect; but object to all corporation laws winich entorce a distinction not recognised by the colleges of England. I do not enter into the question whether obstetricy is a branch of medicine or of surgery; but it is quite notorious that the most distinguished practitioners of obstetricy are rhvsicians.

Jan. 1859. Robeet Wollaston, M.D., F.R.C.S., \&c.

\section{COLLEGE OF DENTISTS OF ENGLAND.}

\section{LECTURES ON THE MEDICAL HISTORY AND TREAT. MENT OF DISEASES OF THE TEETH.}

ON Tuesday night, the 18 th ult., the lecture delivered by Dr. Richardson at the College was on the "History of Malignant Diseases involving the Organs of Mastication." The first part of the lecture embraced topics relating to the pathology, the causes, and the course of cancerous growths. The lecturer gave very clear and decided views in support of the systemic origin of the disease, and in favour of cancer being the product of a matter eliminated from the blood. He took some pains, however, to explain a theory held by Dr. Snow as to the origin of malignant disease, not from diseased blood, but from changes of nutrition, purely local, and confined to the affected part. The general and local symptoms of malignant diseuses having been discussed, the varieties of cancer enumerated, and the theories as to the cause of cancer illustrated, the questions of hereditary influence and of the possible contagious character of cancer were brought forward. Dr. Richardson, after narrating the experiments which had been performed with the view of ascertaining whether cancer was transmissible by inoculation, admitted that experiment tended to negative that view, but adduced the history of cases, one of which had betn recorded in The Lascer by hinself, which lec?, after all, to the supposi. tion that the disease could be so commanicated from one indivi. dual to another. Tr. Richardson now passed to the consideration of those malirmant liseases which are met with in the neighbourhood of the dental structures: namely, malignant diserse of the antrum, malignant disease commencing as polypus of the nose, malimant tumour of the bony structure of the maxille, and epithelial cancer of the lip and cheek. Each of these forms of disease was marked out with much precision, special care being lestowed on the description of the early stages, and on points of diagnosis.

In entering on the subject of treatment, the lecturer re marked that the practitioner of dentistry, in meeting with doubtful cases of malignant disease, had two points to bear in mind: first, to use such means as science may supply to him of ascertaining the nature and position of the disease; and secondly, to use such measures as come within the scope of his own art to remove sources of local irritation: but these simple rules obeyed, and the malignant character of the malady identified, the rest, in way of treatment, belonged to the surgeon or physician. Finaliy. Dr. Richardson summed up the prin. ciples which were striven after in the matter of medical and surgical treatment. The treatment by local means, excision and removal by caustics, was considered; and the advantages versus the disadvantages of removal, as a simple practice, were balanced. But if extirpation were decided on, as right in the abstract, excision, it was urged, had the decided preference, and was the means to be employed. "For what," asked the lecturer, "can caustics perform which the knife cannot be made to do more effectually, more speedily, and, in the end, with infinitely less pain thau any caustic known?" Regarding general remedies, he further observed, that while, as yet, no spe cific was known, it was to be hoped that a chemical remedy would be discovered as effective as quinine is effective in ague and arsenic in lepra. Wieanwhile, the best general remedy for the cancer-stricken man is exercise on the hills, where flowers grow, the sun really shines, and the pure air ofiers that lease of life which physic, out of her many resources, has as yet failed to supply.

\section{COURT OF QUEEN'S BENCH.}

$$
\text { JAN. 29, } 1859 .
$$

(Before Lord Campseli and Justices Wighrmar, Cromptos, and HILL.)

\section{REGINA $v$. STORRAR}

THe A TrORNEY-GExERAL stated that he had been instruct $d$ on behalf of the Senate of the University of Loudon to show cause against a rule which had been obtained, calling upon Dr. John Storrar to show cause why an information in the nature of a quo warranto should not be filed against him, on the ground that he had been unduly elected to the Medical General Council. He felt the question to be so important, as affecting the rights of a large body of influential persons, and their Lordships would probably be of opinion that there was so much force in the arguments adduced by Mr. Edward James in moving for the rule, that he did not feel that he could mal e such a serious opposition as to induce their Lordships to discharge the rule, and he should therefore not resist its being made absolute.

Lord CAMPBEL thought the question was of very great im. portance to all the graduates of the University of London, which had already become a very distinguished body.

The ATrORNeY-Gereral said the question was certainly one of great moment, and if their Lordships thought fit tle question should be raised on tine record.

The rule was accordingly made absolute.

Mr. Edward James, Q.C., and Mr. Littler appeared in support of the rule.

Lord CAMrpelu said the Court would give every facility for having the question heard and disposed of at the earliest opportumity.

The rule being therefore made absolute, the result is, that a step is gained for the graduates; and it is clearly shown that the question is not regarded, either by the Court or by the Atlorney-General, to be so simple or so clearly in favour of the views held by the Senate as seemed at first to be the somewhat general impression. The final argument will take place early next term. 